\title{
GENETIC DIVERSITY AMONG ENDANGERED FRESHWATER MUSSELS BASED ON SHELL DNA SEQUENCES
}

\author{
DOĞANKAYA, L. ${ }^{*}$ - COŞKUN, T. - GÜLTEKIN, T. \\ Ankara University, Faculty of Agriculture, Department of Fisheries and Aquaculture \\ Engineering, 06110 Dışkapı, Ankara, Turkey \\ (phone: +90-312-596-1438; fax: +90-312-318-5298) \\ ${ }^{*}$ Corresponding author \\ e-mail: dogankaya@ankara.edu.tr; phone: +90-312-596-1439; fax: +90-312-318-5298
}

(Received 30 ${ }^{\text {th }}$ Apr 2019; accepted 11 ${ }^{\text {th }}$ Jul 2019)

\begin{abstract}
Molecular genetic information on mollusk species is being increasingly considered for identification and taxonomic status. In this study, we examined the potential of shell material of freshwater mussels from four different locations in Turkey for DNA sequence analysis. A total number of 212 specimens including empty shells were sampled from a river and three lakes. Mitochondrial DNA was extracted from ground shell material with isolation kits and tissue material was also used for reference. Even though the majority of empty shells did not produce high-quality material, DNA extraction from fresh shells had similar results with tissue material. Mitochondrial 28S rDNA partial sequences were analyzed using the neighbour-joining method for genetic divergence. Phylogenetic analysis revealed two well-differentiated clades of Anodonta cygnea and Unio crassus. The results clearly indicated that $28 \mathrm{~S}$ rRNA sequences obtained from shell material are informative enough to reveal major clades, haplotypes and phylogenetic relationship between four populations. These findings support that quite fresh shell material from freshwater mussels can be a convenient DNA source for molecular studies. Keywords: Unionidae, phylogeny, shell DNA, bivalve diversity, $28 S$ rDNA
\end{abstract}

\section{Introduction}

Freshwater mussels as prehistoric bivalve inhabitants of inland waters are represented on all continents except Antarctica. They are classified into six families, about 180 genera and 800 species (Bogan, 2008). Bivalves are remarkable aquatic organisms with heavy impact on ecosystems through filtration, bio-accumulation, energy transfer, being host for other organisms and their role in food web. Such factors as pollution, loss of host fishes and the introduction of non-native species are causing changes in diversity and population structure (Lopez-Lima et al., 2017). Freshwater mussels are globally in decline and are among the most endangered aquatic species (Strayer, 2008). Lopez-Lima et al. (2017) recorded 224 (44\%) of the 511 freshwater mussel species as Near Threatened or Threatened in the 2015 IUCN Red List of Threatened Species. Despite having highly important ecosystem roles, gaps exist on biology and population structure of freshwater bivalves still standing as the primary obstacle to management and conservation.

Recently, European freshwater mussels have also been gaining increasing attention and 16 species have been recognized in Unionida Margaritiferidae: 2 and Unionidae: 14 (Lopez-Lima et al., 2017). The current taxonomy of freshwater mussels is based on morphological characteristics and studies on genetic diversity are very scarce. Due to variable characteristics as size and shell shape which are affected by the current velocity, substratum and environment, freshwater mussels exhibit high phenotypic plasticity (Baker et al., 2004). 
Population size, distribution and species data are primary requirements for successful conservation management so the taxonomic status of the order Unionida is to be resolved and DNA sequence would serve valuable data for systematic updates.

Mantle clipping is the widespread method for tissue sampling from mollusks in genetic studies but non-invasive sampling methods are needed for endangered species and in case of lacking live specimens. Henley et al. (2006) described integumental swabbing as a noninvasive method for cell collection from freshwater mussels. A more recent study presented a method for DNA extraction from empty apple snail shells (Andree and Lopez, 2013).

To avoid the phenomenon phenotypic plasticity and facilitate genetic analysis through small shell fragments from live or empty shells, we examined genetic diversity in four populations of freshwater mussels using $28 \mathrm{~S}$ rDNA sequences. Here we present a successful method and first genetic data on Turkish populations of freshwater mussels.

\section{Materials and Methods}

\section{Live specimens and empty freshwater mussel shells}

Freshwater mussels and empty shells were collected from Gölmarmara/Manisa (lake), Manavgat/Antalya (dam lake downstream), Küçük Akgöl/Adapazarı (lake), Karasu/Sinop (river) in Turkey (Table 1) with the permission of the Ministry of Agriculture and Forestry (Figure la). While empty shells were placed in plastic bags, tissue samples were taken from live specimens into ethanol $70 \%$ and transferred to the laboratory in cooler boxes. Samples were stored at $-20^{\circ} \mathrm{C}$ until analysis.

Table 1. Sampling locations

\begin{tabular}{c|c|c|c}
\hline Location & Waterbody & Coordinates & Number of specimens \\
\hline Karasu & Stream & $41.56162 " \mathrm{~N}-35.04827 " \mathrm{E}$ & 150 \\
Küçük Akgöl & Lake & $40.52365 " \mathrm{~N}-30.25582 " \mathrm{E}$ & 40 \\
Gölmarmara & Lake & $38.35449 " \mathrm{~N}-27.59487 " \mathrm{E}$ & 4 \\
Manavgat & Dam Lake & $36.52434 " \mathrm{~N}-31.31211^{\mathrm{E}} \mathrm{E}$ & 11 \\
\hline
\end{tabular}

\section{DNA preparation, PCR and sequencing}

Total DNA was extracted using EurX GeneMATRIX Tissue \& Bacterial DNA Purification Kit (Poland) according to the manufacturer protocol with minor modifications. Samples from each shell were removed with an $8 \mathrm{~mm} \varnothing$ ceramic cutting hand drill and crushed into fine powder in a mortar. To avoid contamination, cutting edges were changed with new between samples. Sample material was placed into the $2 \mathrm{ml}$ tube and $350 \mu \mathrm{l}$ Lyse $\mathrm{T}$ buffer added and the precipitate was suspended. Tissue samples were cut into small pieces and buffered. $2 \mu 1$ RNaseA and $20 \mu$ l Proteinase K were added and vortexed. Samples were incubated at $56^{\circ} \mathrm{C}$ during $3 \mathrm{~h}$ after adding $350 \mu \mathrm{l}$ buffer, the samples were incubated for $10 \mathrm{~min}$ at $70^{\circ} \mathrm{C}$. Pure ethanol of $350 \mu \mathrm{l}$ was added and the tubes were centrifuged for $1 \mathrm{~min}$ at $12000 \mathrm{~g}$. The supernatant was transferred into DNA binding spin-column and centrifuged repeatedly. After placing the column in the collection tube $500 \mu \mathrm{l}$ washing buffers were added and centrifuged. Elution buffer was added in new tubes and incubated at room temperature. DNA products were stored at $4^{\circ} \mathrm{C}$. The recovered DNA was checked with Thermo Scientific Nanodrop 2000 (USA) for integrity. 


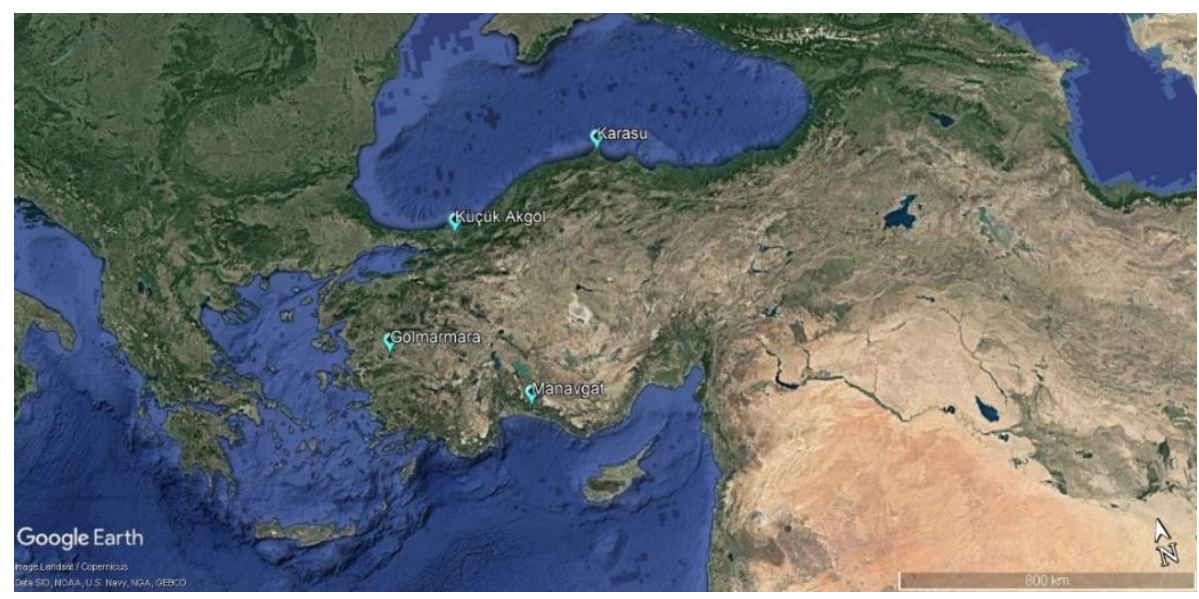

Figure 1a. Map showing the sampling locations

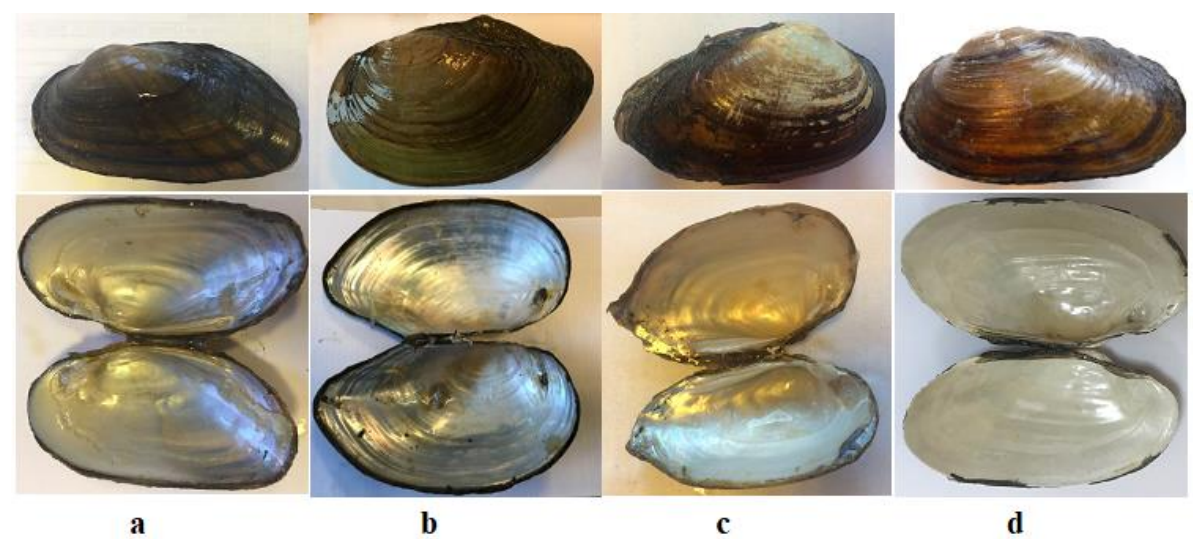

Figure 1b. Shells from collection sites. (a)Karasu, (b)Akgöl, (c) Gölmarmara and (d) Manavgat

A universal primer set (Justine et al., 2002) was employed for mitochondrial 28S rDNA gene amplification (Table 2).

Table 2. Primer set used for $28 S$ rDNA amplification

\begin{tabular}{c|c|c|c}
\hline Primer & Direction & Primer Sequence & Reference \\
\hline C1 & Forward & 5'-ACCCGCTGAATTTAAGCAT-3' & \multirow{2}{*}{ Justin et al., 2002} \\
C2 & Reverse & 5'-CTCTCTYTYCAAAGTTCTTTTC-3' & \\
\hline
\end{tabular}

Each PCR reaction mixture contained $1.5 \mu \mathrm{l}$ DNA template $(880 \mathrm{ng} / \mu \mathrm{l}), 1 \mu \mathrm{l}$ DNA FIREPol ${ }^{\circledR}$ DNA Polymerase $(5 \mathrm{U} / \mu \mathrm{l}), 10 \mu \mathrm{l}$ 10X Buffer, $1 \mu \mathrm{l}$ dNTP $(20 \mathrm{mM}), 6 \mu 125$ $\mathrm{mM} \mathrm{MgCl} 2(1.5 \mathrm{nM})$ and $10 \mathrm{pmol} / \mu \mathrm{l}$ of each primer $(0.15 \mu \mathrm{M})$, completed with $\mathrm{ddH}_{2} \mathrm{O}$ to a total volume of $100 \mu$. The thermal cycler profile was as one cycle initial denaturation step at $95^{\circ} \mathrm{C}$ for $5 \mathrm{~min}, 35$ cycles of denaturation at $95^{\circ} \mathrm{C}$ for $45 \mathrm{sec}$, annealing at $57^{\circ} \mathrm{C}$ for $45 \mathrm{sec}$, elongation at $72^{\circ} \mathrm{C}$ for $1 \mathrm{~min}$ and a final extension step at $72^{\circ} \mathrm{C}$ for $5 \mathrm{~min}$. The amplified DNA fragments were controlled with agarose gel electrophoresis and purified using ExoSAP-ITTM PCR Product Cleanup Reagent" 
(ThermoFisher Scientific, USA). PCR amplified DNA fragments were sequenced with automated 3500xL Genetic Analyzer (Applied Biosystems).

The sequences were aligned with Sequencer v5.4.6 and consensus alignments for each sampling location were deposited to GenBank under accession numbers MK530498, MK530499, MK530500, MK530501.

The number of polymorphic sites, DNA polymorphism, conserved regions, haplotype number, haplotype diversity and Tajima's D statistics were performed with DnaSP v.5.0 (Librado and Rozas, 2009).

Phylogenetic analysis for the 28S rDNA sequence set was performed using the software MEGA X (Kumar et al., 2018). The tree was produced with the NeighborJoining (NJ) method using the Kimura 2-parameter model for genetic distance estimation (Kimura, 1980). Percentage of replicate trees in the bootstrap test (1000 replicates) indicated alongside the branch nodes (Felsenstein, 1985).

\section{Results}

DNA extraction from all three types of material was affordable. Figure 2 demonstrates the gel electrophoresis screenshot for mitochondrial DNA from mantle clipping, fresh shell and old empty shell material. Even though mitochondrial DNA can be isolated from all samples, sequencing performance was not the same. While $97 \%$ of tissue and $70 \%$ of fresh shell samples were sequenced succesfully, only $10 \%$ of the PCR products from old empty shells served quality sequences (Table 3).

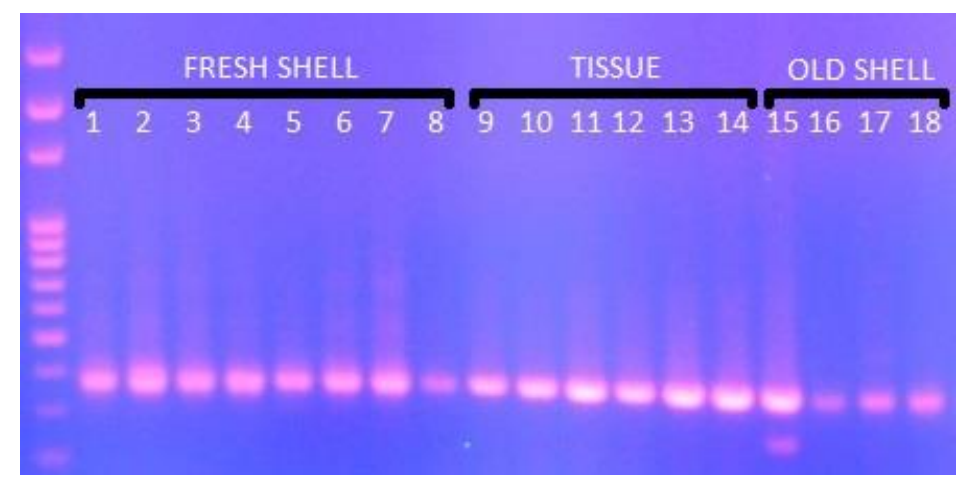

Figure 2. Gel electrophoresis of mantle tissue, fresh shell and old shell samples

Table 3. Number of successfully sequenced specimens from different DNA sources

\begin{tabular}{c|c|c|c|c|c|c}
\hline & \multicolumn{2}{|c|}{ Tissue } & \multicolumn{2}{c|}{ Fresh Shell Material } & \multicolumn{2}{c}{ Old Empty Shell Material } \\
\hline Location & $\begin{array}{c}\text { Template } \\
\text { DNA (n) }\end{array}$ & $\begin{array}{c}\text { Sequenced } \\
\text { (n) }\end{array}$ & $\begin{array}{c}\text { Template } \\
\text { DNA (n) }\end{array}$ & $\begin{array}{c}\text { Sequenced } \\
(\mathbf{n})\end{array}$ & $\begin{array}{c}\text { Template } \\
\text { DNA (n) }\end{array}$ & $\begin{array}{c}\text { Sequenced } \\
\text { (n) }\end{array}$ \\
\hline Karasu & 10 & 10 & 10 & 10 & 10 & 2 \\
Küçük Akgöl & 10 & 10 & 10 & 7 & 10 & - \\
Gölmarmara & 6 & 5 & 6 & 4 & 10 & 1 \\
Manavgat & 10 & 10 & 10 & 4 & 10 & 1 \\
\hline
\end{tabular}

Twenty-five 28S rDNA sequences have an average length of $339 \mathrm{bp}$. Mean G+C ratio found $54.1 \%$ ranging between a high scale of min $52.9 \%$ and max $54.8 \%$. (Table 4). Specimens from each sampling location were given in consensus sequences 
in NJ tree construction. Nucleotide compositions of consensus sequences are given in Table 4.

For all data set, 136 variable sites exist in 339 bg sequence (5.04\%). Table 5 shows conserved, variable and parsimony informative sites, identical, transitional and transversional pair frequencies and transition/transversion ratio $(\mathrm{R})$. The data set has 82 polymorphic and 52 parsimony informative sites and transitional/transversional pair ratio of $0.8(\mathrm{R})$.

Table 4. Nucleotide composition

\begin{tabular}{c|c|c|c|c|c|c}
\hline Location & T $(\mathbf{U})$ & $\mathbf{C}$ & $\mathbf{A}$ & $\mathbf{G}$ & $\mathbf{G + C}$ & $\mathbf{A + T}$ \\
\hline Karasu & 20.4 & 24.3 & 26.7 & 28.5 & 52.9 & 47.1 \\
Küçük Akgöl & 20.1 & 24.7 & 25.6 & 29.6 & 54.3 & 45.7 \\
Gölmarmara & 19.6 & 25.2 & 25.8 & 29.5 & 54.7 & 45.3 \\
Manavgat & 20.4 & 24.5 & 24.8 & 30.3 & 54.8 & 45.2 \\
Avg. & 20.1 & 24.7 & 25.7 & 29.5 & 54.1 & 45.9 \\
\hline
\end{tabular}

Table 5. Nucleotide pair frequency

\begin{tabular}{c|c} 
Conserved sites & $199 / 339$ \\
Variable sites & $136 / 339$ \\
Parsimony informative sites & $52 / 339$ \\
Singleton sites & $83 / 339$ \\
Identical pairs ii & 259 \\
Transitional pairs si & 10 \\
Transversional pairs sv & 13 \\
R si/sv & 0.8
\end{tabular}

The sequence data set represented 16 haplotypes. While haplotype H9 existed in six samples ( 2 from Golmarmara and 4 from Akgol), haplotype H10 was found in three samples (1 from Golmarmara, 1 from Akgol and 1 from Manavgat). Other 14 haplotypes were found for each sample from all locations. Mean haplotype diversity $(\mathrm{Hd})$, nucleotide diversity $(\pi)$, Tajima's D test results are given in Table 6. Haplotype diversity changed between 0.714 and $1.000 \mathrm{~min} / \mathrm{max}$ from Akgöl and Manavgat. Average $\mathrm{Hd}$ and $\pi$ were calculated as 0.0881 and 0.062 respectively. Test of neutrality on allele frequency distribution with Tajima's D indices resulted negative for all four populations and was not statistically significant $(\mathrm{p}>0.05)$.

Table 6. Genetic diversity and neutrality results (Hd: Haplotype diversity, $\pi$ : nucleotide diversity)

\begin{tabular}{c|c|c|c|c|c}
\hline Location & $\mathbf{n}$ & $\mathbf{h}$ & Hd & $\boldsymbol{\pi}$ & Tajima's D \\
\hline Karasu & 10 & 9 & 0.977 & 0.065 & -0.419 \\
Küçük Akgö1 & 7 & 4 & 0.714 & 0.117 & -1.543 \\
Gölmarmara & 4 & 3 & 0.833 & 0.006 & -0.780 \\
Manavgat & 4 & 4 & 1.000 & 0.059 & -0.635 \\
\hline
\end{tabular}

Nucleotide substitution rates were calculated with maximum likelihood method using Tamura 3-parameter model (Table 7). The nucleotide frequencies are $\mathrm{A}=23.13 \%$, $\mathrm{T} / \mathrm{U}=23.13 \%, \mathrm{C}=26.87 \%$, and $\mathrm{G}=26.87 \%$. 
The divergence between four populations ranged between 0.019 and 0.045 with an average value of 0.031 (3.1\%) indicating a correlation between divergence and location. While the highest diversity was found between Karasu and Manavgat populations (4.5\%), the populations from Gölmarmara and Akgöl were the genetically closest ones $(1.9 \%)$ (Table 8). The high distance value of Karasu samples is due to the species difference. The Karasu population is clearly located on a separate branch in the phylogenetic tree given in Figure 3.

Table 7. Nucleotide substitution matrix

\begin{tabular}{c|cccc}
\hline & $\mathbf{A}$ & $\mathbf{T}$ & $\mathbf{C}$ & $\mathbf{G}$ \\
\hline $\mathbf{A}$ & - & 6.77 & 7.86 & $\mathbf{1 1 . 1 5}$ \\
$\mathbf{T}$ & 6.77 & - & $\mathbf{1 1 . 1 5}$ & 7.86 \\
$\mathbf{C}$ & 6.77 & $\mathbf{9 . 6 0}$ & - & 7.86 \\
$\mathbf{G}$ & $\mathbf{9 . 6 0}$ & 6.77 & 7.86 & - \\
\hline
\end{tabular}

Each entry is the probability of substitution ( $r$ ) from one base (row) to another base (column). Rates of different transitional substitutions are shown in bold and those of transversional substitutions are shown in italics

Table 8. Average p distances for $28 S$ rDNA between different geographic populations

\begin{tabular}{c|c|cccc}
\hline $\mathbf{n}$ & & $\mathbf{1}$ & $\mathbf{2}$ & $\mathbf{3}$ & $\mathbf{4}$ \\
\hline $\mathbf{4}$ & Manavgat & - & & & \\
$\mathbf{7}$ & Akgol & 0.028 & - & & \\
$\mathbf{4}$ & Golmarmara & 0.019 & 0.003 & - & - \\
$\mathbf{1 0}$ & Karasu & 0.045 & 0.044 & 0.045 & - \\
\hline
\end{tabular}

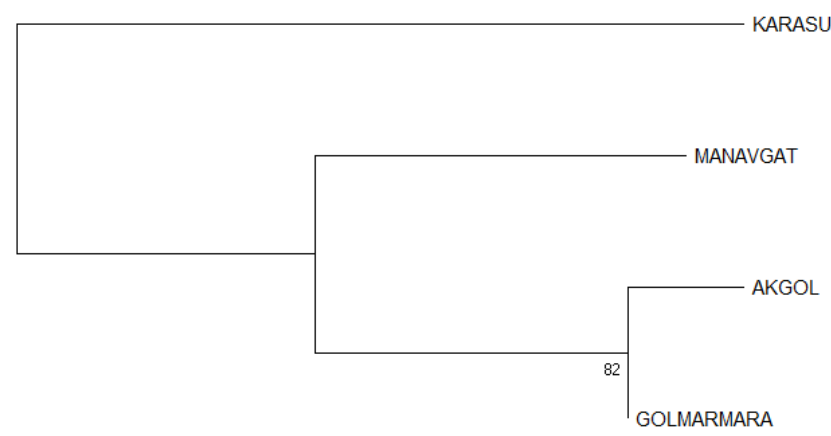

0,005

Figure 3. Phylogenetic relationships among four taxa inferred from 28S rDNA sequences. The evolutionary history was inferred using the Neighbor-Joining method (Saitou and Nei, 1987).

The percentage of replicate trees in which the associated taxa clustered together in the bootstrap test (1000 replicates) are shown next to the branches (Felsenstein, 1985). The evolutionary distances were computed using the Kimura 2-parameter method (Kimura, 1980).

Evolutionary analyses were conducted in MEGA X (Kumar et al., 2018)

Figure 3 shows the evolutionary relationship between the four populations. The tree was obtained by Neighbor-Joining method (Saitou and Nei, 1987) in MEGA X (Kumar 
et al., 2018). The optimal tree with the sum of branch length was 0,058775. Genetic distances between four populations were estimated by Kimura 2-parameter method (Kimura, 1980). The percentage of replicate trees in which the associated taxa clustered together in the bootstrap test (1000 replicates) are shown next to the branches (Felsenstein, 1985). The analysis involved 4 nucleotide sequences. All ambiguous positions were removed for each sequence pair. There were a total of 339 positions in the final dataset.

\section{Discussion}

This is the first study investigating the genetic diversity of freshwater bivalvia through shell DNA analysis. The results clearly indicated that $28 \mathrm{~S}$ rRNA sequences obtained from shell material are informative to reveal major clades, haplotypes and phylogenetic relationship between four populations. These findings support that quite fresh shell material from freshwater mussels is to be a convenient DNA source for molecular-based studies. Degradation of shells due to the exposure time to environmental components, basically the water, is the primary limiting factor for shell DNA.

$\mathrm{G}+\mathrm{C}$ ratio (average 54.1\%) represented in Table 4 indicates heterogeneity between four populations. The high number of variable sites supports that the $339 \mathrm{bp} 28 \mathrm{~S}$ rRNA sequence from the shell is a successful molecular marker for freshwater mussels. Transitional/Transversional pair rate $\mathrm{R}(\mathrm{si} / \mathrm{sv}$ ) found 0.8 while substitution rate $\mathrm{R}$ which is calculated using Kimura-2 parameter was 0.7. These close rates also support the reliability of data analysis.

Consensus sequence analyses supported two well-differentiated clades of unionid species swan mussel Anodonta cygnea from Manavgat, Akgol and Golmarmara Lakes and thick shelled river mussel Unio crassus from Karasu River. Genetic distance between populations found between 0.003 and 0.045 (Table 8) with an average of 0.030. Akgol and Golmarmara populations have exhibited the lowest genetic distance while Karasu River samples have a constant high distance value which is compatable with species difference.

According to Gürlek et al. (2014) Modell has defined four main groups of freshwater mussels of Anatolia according to geographic distribution containing Unio, Anodonta, Potomida, Leguminaia, Gabillotia, Pseudodontopsis, Sinanodonta species. There are only a few more studies on freshwater mollusks of Turkey which all used the morphological description of species. This study is being the first as using shell DNA for genetic classification of freshwater bivalvia from Turkey. Due to the difference between sampling locations, there is a lack of chance to conclude data from the literature. Only Şahin (2013) defined bivalvia specimens from Karasu as Unio pictorum through morphological identification methods but our findings indicated a different taxonomy of specimens from the same locality as Unio crassus according mtDNA sequence.

The phylogenetic tree of 28S rRNA sequences clearly revealed the genetic difference between four populations (Figure 3). Karasu samples were located on a separate branch. Akgol and Golmarmara populations stand close with a result of the hypotheses of geographic isolation.

Ricciardi and Rasmussen (1999) have reported the rapid extinction of freswater species in Nort America and made an extinction rate estimation for freshwater mussels 
about two fold than the avarage of freshwater species. Lopes-Lima et al. (2017) have underlined the lack of data on freshwater mussels especially in south-eastern European countries and the importance of more studies for effective management measures.

While thick shelled river mussel Unio crassus is classified as "globally endangered" on IUCN Red List (Lopes-Lima et al., 2014), the swan mussel Anodonta cygnea is referred as "near threatened" by Killeen and Aldridge (2011). Also, it is noted that the population trend of Unio crassus is unknown for the Mediterranean basis so referred to DD (Data Deficient) by Vavrova (2011). Since the taxonomy of freshwater bivalve is still ambiguous and species distribution and population sizes are unclear, molecular studies can serve valuable information for conservation management plans.

\section{Conclusion}

The need for effective conservation and management strategies for freshwater ecosystems which are under intense pressure, especially human activities, requires wider monitoring using standardized protocols and methods. But there are gaps on population structures, distribution and taxonomic data for many species as well as freshwater mussels. On country basis, large scale taxonomic studies which are supported with molecular data will help filling these gaps. International cooperation is strongly suggested for database and management projects.

Overall this study suggests shell DNA as a reliable source of divergence data on freshwater bivalve species against the problematic systematic relationships and phenotypic plasticity. Partial sequences of $28 \mathrm{~S}$ rDNA derived from four populations provide the first genetic data in Turkey with this study.

Future researches are needed for large scale data collection on freshwater bivalves by using non-invasive standardized methods.

Acknowledgments. This research has been supported by Ankara University Scientific Research Projects Coordination Unit. Project Number: 16B0759001, 2018.

\section{REFERENCES}

[1] Andree, K. B., López, M. A. (2013): Species identification from archived snail shells via genetic analysis: a method for DNA extraction from empty shells. - Molluscan Research 33(1): $1-5$.

[2] Baker, A. M., Sheldon, F., Somerville, J., Walker, K. F., Hughes, J. M. (2004): Mitochondrial DNA phylogenetic structuring suggests similarity between two morphologically plastic genera of Australian freshwater mussels (Unionoida: Hyriidae). Molecular Phylogenetics and Evolution 32(3): 902-912.

[3] Bogan, A. E. (2008): Global diversity of freshwater mussels (Mollusca, Bivalvia) in freshwater. - Hydrobiologia 595: 139-147.

[4] Felsenstein, J. (1985): Confidence limits on phylogenies: An approach using the bootstrap. - Evolution 39: 783-791.

[5] Gürlek, M., Kara, C., Kebapçı, Ü. (2014): Adıyaman Azaplı Gölü'nde yaşayan Unio terminalis (Bourguignat, 1852)'in bazı konkolojik özellikleri. - Aquaculture Studies 2014(3): 23-28.

[6] Henley, W. F., Grobler, P. J., Neves, R. J. (2006): Non-invasive method to obtain DNA from freshwater mussels (Bivalvia: Unionidae). - Journal of Shellfish Research 25(3): 975-978. 
[7] Justine, J. L., Jovelin, R., Neifar, L., Mollaret, I., Lim, L. H. S., Hendrix, S. S., Euzet, L. (2002): Phylogenetic positions of the Bothitrematidae and Neocalceostomatidae (monopisthocotylean monogeneans) inferred from $28 \mathrm{~S}$ rDNA sequences. - Comparative Parasitology 69(1): 20-25.

[8] Killeen, I., Aldridge, D. (2011): Anodonta cygnea. - The IUCN Red List of Threatened Species 2011: e.T156066A4907255. Downloaded on 25 April 2019.

[9] Kimura, M. (1980): A simple method for estimating evolutionary rate of base substitutions through comparative studies of nucleotide sequences. - Journal of Molecular Evolution 16: 111-120.

[10] Kumar, S., Stecher, G., Li, M., Knyaz, C., Tamura, K. (2018): MEGA X: Molecular Evolutionary Genetics Analysis across computing platforms. - Molecular Biology and Evolution 35: 1547-1549.

[11] Librado, P., Rozas, J. (2009): DnaSP v5: A software for comprehensive analysis of DNA polymorphism data. - Bioinformatics 25: 1451-1452.

[12] Lopes-Lima, M., Kebapçı, U., Van Damme, D. (2014): Unio crassus. - The IUCN Red List of Threatened Species 2014: e.T22736A42465628. http://dx.doi.org/10.2305/IUCN.UK.2014-1.RLTS.T22736A42465628.en. Downloaded on 25 April 2019.

[13] Lopes-Lima, M., Sousa, R., Geist, J., Aldridge, D. C., Araujo, R., Bergengren, J., Douda, K. (2017): Conservation status of freshwater mussels in Europe: state of the art and future challenges. - Biological Reviews 92(1): 572-607.

[14] Ricciardi, A., Rasmussen, J. B. (1999): Extinction rates of North American freshwater fauna. - Conservation Biology 13: 1220-1222.

[15] Saitou, N., Nei, M. (1987): The neighbor-joining method: A new method for reconstructing phylogenetic trees. - Molecular Biology and Evolution 4: 406-425.

[16] Strayer, D. L. (2008): Freshwater Mussel Ecology: A multifactor approach to distribution and abundance. - University of California Press, Berkeley, CA.

[17] Şahin, S. K. (2013): Mollusca species of Down Sakarya River (Karasu) and some physico-chemical variables effecting their abundance. - Aquaculture Studies 13: 011-019.

[18] Vavrova, L. (2011): Unio crassus. - The IUCN Red List of Threatened Species 2011: e.T22736A9382322. Downloaded on 25 April 2019. 